NASA/TM-2004-213100
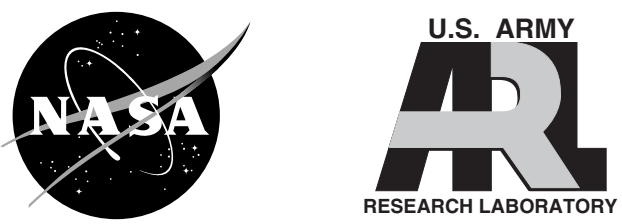

\title{
An Experimental Investigation Into the Temperature Profile of a Compliant Foil Air Bearing
}

Kevin Radil

U.S. Army Research Laboratory, Glenn Research Center, Cleveland, Ohio

Michelle Zeszotek

Purdue University, West Lafayette, Indiana 
Since its founding, NASA has been dedicated to the advancement of aeronautics and space science. The NASA Scientific and Technical Information (STI) Program Office plays a key part in helping NASA maintain this important role.

The NASA STI Program Office is operated by Langley Research Center, the Lead Center for NASA's scientific and technical information. The NASA STI Program Office provides access to the NASA STI Database, the largest collection of aeronautical and space science STI in the world. The Program Office is also NASA's institutional mechanism for disseminating the results of its research and development activities. These results are published by NASA in the NASA STI Report Series, which includes the following report types:

- $\quad$ TECHNICAL PUBLICATION. Reports of completed research or a major significant phase of research that present the results of NASA programs and include extensive data or theoretical analysis. Includes compilations of significant scientific and technical data and information deemed to be of continuing reference value. NASA's counterpart of peerreviewed formal professional papers but has less stringent limitations on manuscript length and extent of graphic presentations.

- TECHNICAL MEMORANDUM. Scientific and technical findings that are preliminary or of specialized interest, e.g., quick release reports, working papers, and bibliographies that contain minimal annotation. Does not contain extensive analysis.

- CONTRACTOR REPORT. Scientific and technical findings by NASA-sponsored contractors and grantees.
- CONFERENCE PUBLICATION. Collected papers from scientific and technical conferences, symposia, seminars, or other meetings sponsored or cosponsored by NASA.

- SPECIAL PUBLICATION. Scientific, technical, or historical information from NASA programs, projects, and missions, often concerned with subjects having substantial public interest.

- TECHNICAL TRANSLATION. Englishlanguage translations of foreign scientific and technical material pertinent to NASA's mission.

Specialized services that complement the STI Program Office's diverse offerings include creating custom thesauri, building customized databases, organizing and publishing research results ... even providing videos.

For more information about the NASA STI Program Office, see the following:

- Access the NASA STI Program Home Page at http://www.sti.nasa.gov

- E-mail your question via the Internet to help@sti.nasa.gov

- Fax your question to the NASA Access Help Desk at 301-621-0134

- Telephone the NASA Access Help Desk at 301-621-0390

- Write to:

NASA Access Help Desk

NASA Center for AeroSpace Information 7121 Standard Drive

Hanover, MD 21076 
NASA/TM-2004-213100
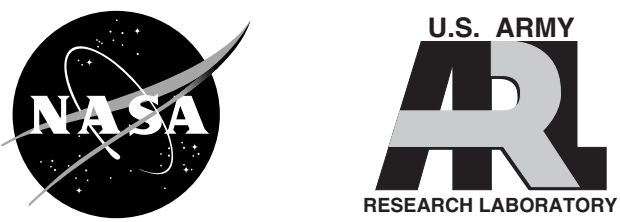

\section{An Experimental Investigation Into the Temperature Profile of a Compliant Foil Air Bearing}

Kevin Radil

U.S. Army Research Laboratory, Glenn Research Center, Cleveland, Ohio

Michelle Zeszotek

Purdue University, West Lafayette, Indiana

Prepared for the

2004 Annual Meeting and Exhibition

sponsored by the Society of Tribologists and Lubrication Engineers

Toronto, Canada, May 17-20, 2004

National Aeronautics and

Space Administration

Glenn Research Center 


This report contains preliminary
findings, subject to revision as
analysis proceeds.

Available from

NASA Center for Aerospace Information 7121 Standard Drive

Hanover, MD 21076
National Technical Information Service 5285 Port Royal Road Springfield, VA 22100

Available electronically at http://gltrs.grc.nasa.gov 


\title{
An Experimental Investigation Into the Temperature Profile of a Compliant Foil Air Bearing
}

\author{
Kevin Radil \\ U.S. Army Research Laboratory \\ Glenn Research Center \\ Cleveland, Ohio 44135 \\ Michelle Zeszotek \\ Purdue University \\ West Lafayette, Indiana 47907
}

\begin{abstract}
A series of tests was performed to determine the internal temperature profile in a compliant bumptype foil journal air bearing operating at room temperature under various speeds and load conditions. The temperature profile was collected by instrumenting a foil bearing with nine, type $\mathrm{K}$ thermocouples arranged in the center and along the bearing's edges in order to measure local temperatures and estimate thermal gradients in the axial and circumferential directions. To facilitate the measurement of maximum temperatures from viscous shearing in the air film, the thermocouples were tack welded to the backside of the bumps that were in direct contact with the top foil. The mating journal was coated with a high temperature solid lubricant that, together with the bearing, underwent high temperature start-stop cycles to produce a smooth, steady-state run-in surface. Tests were conducted at speeds from 20 to $50 \mathrm{krpm}$ and loads ranging from 9 to $222 \mathrm{~N}$.

The results indicate that, over the conditions tested, both journal rotational speed and radial load are responsible for heat generation with speed playing a more significant role in the magnitude of the temperatures. The temperature distribution was nearly symmetric about the bearing center at 20 and $30 \mathrm{krpm}$ but became slightly skewed toward one side at 40 and $50 \mathrm{krpm}$. Surprisingly, the maximum temperatures did not occur at the bearing edge where the minimum film thickness is expected but rather in the middle of the bearing where analytical investigations have predicted the air film to be much thicker. Thermal gradients were common during testing and were strongest in the axial direction from the middle of the bearing to its edges, reaching $3.78^{\circ} \mathrm{C} / \mathrm{mm}$. The temperature profile indicated the circumferential thermal gradients were negligible.
\end{abstract}

\section{Introduction}

Compliant foil bearings are at the forefront of the Oil-Free turbomachinery revolution of supporting gas turbine engines with air lubricated hydrodynamic bearings. Foil air bearings have existed for almost fifty years yet their commercialization has been confined to relatively small, high-speed systems characterized by low temperatures and loads, such as in air cycle machines, turbocompressors and microturbines. Recent breakthroughs in foil air bearing design (ref. 1) and solid lubricant coating technology (ref. 2), however, have caused a resurgence of research towards applying Oil-Free technology to more demanding applications on the scale of small and mid range aircraft gas turbine engines. A technology insertion of this type will eliminate oil and supply hardware resulting in substantial benefits to the aerospace community. According to a NASA Glenn Research Center in-house system study, when compared to current engine designs, future Oil-Free gas turbine engines will weigh 15 percent less, have a power density increase of 20 percent or more and will reduce maintenance costs of 50 percent (ref. 3 ). 
The Oil-Free turbomachinery team at NASA Glenn is working to foster the transition of Oil-Free technology into gas turbine engines by performing in-house experiments on foil air bearings to further the understanding of their complex operating principles.

Most turbomachinery systems, such as gas turbine engines, currently rely on ball and/or roller bearings to provide support for the high-speed rotating shafts. These bearings require the use of an oil lubrication system in order to remove excess heat and harmful contaminants and to lubricate the balls, the inner and outer races and also the cages to prevent these parts from seizing together due to friction welding. The oil plays a vital role in the successful operation of the turbomachinery system and, understandably, its well being garners a great deal of attention.

One major concern is overheating of the oil especially if a bearing is located near a hot component, such as the combustion chamber or turbine. Typical gas turbine engine lubricating oil can tolerate temperatures up to approximately $200{ }^{\circ} \mathrm{C}$, but beyond this it begins to thermally degrade, causing the oil to become more acidic and viscous and rendering it ineffective at performing its multi-task functions (ref. 4). In contrast to oil lubricated bearings, foil air bearings are not susceptible to these specific problems since its working fluid does not thermally degrade. Their inherent thermal constraints depend upon the temperature limits of the material used in the bearing's construction and the magnitude of any developing internal temperature gradients.

Among the foil air bearings currently being applied to Oil-Free turbomachinery systems are the bump foil type as shown in the cross-sectional view in figure 1. This bearing consists of a smooth top foil (the bearing surface) resting on a support structure made from strips of corrugated bumps. Each individual bump acts as a small spring and, collectively, forms a compliant support structure that influences the bearing's hydrodynamics, maximum load capacity and stiffness and damping characteristics. The top and bump foils are typically made from a nickel-based superalloy material chosen, when compared to other materials, for its higher elastic modulus in the expected range of operating temperatures. Even though it has superior performance the superalloy is not impervious to heat and will suffer material softening as its temperature increases. As the curve in figure 2 demonstrates there is a definite trend toward a decrease in the material's modulus of elasticity for increasingly higher temperatures. This can have a detrimental impact on the bearing's performance.

For example, DellaCorte measured the performance of foil bearings at various temperatures and speeds and found that increasing the ambient temperature from 23 to $538{ }^{\circ} \mathrm{C}$ degraded the bearing's maximum load capacity (ref. 5). Howard (ref. 6) experimentally measured the stiffness and damping properties of a foil bearing and showed qualitatively that stiffness decreased by a factor of 2 from 25 to $538{ }^{\circ} \mathrm{C}$ and the damping mechanism transformed from being viscous to more frictional. Both researchers concluded that the reduction of bearing performance observed at higher temperatures was attributed to a decrease in the material's elastic properties. It should be noted, however, that the bearing's design can be customized to take into account temperature's effects on the material's properties in order to ensure that load capacity is not lost.

During operation the internal temperatures are dependent upon three factors, the temperature of the surrounding environment, the heat generated by viscous shearing in the thin air film and, to a lesser extent, compression work caused by the shaft pumping air from ambient to a higher pressure region. Even though air's viscosity is low - several orders of magnitude below liquid lubricants - the required high shaft rotational speeds coupled with an air film on the order of $10^{-6} \mu \mathrm{m}$ thick make for a very large velocity gradient that leads to localized heating in the bearing. Since air's heat capacity coefficient is low, when compared to a metallic material, it can be expected that any generated heat will be mostly absorbed by the surrounding surfaces, in this case the top foil and shaft surface. Such was the conclusion made by Salehi who used a Couette Approximation to the energy equation to analytically predict resulting temperatures in a foil air bearing. Based on his work he estimates that 80 percent of the heat is absorbed via conduction into the journal and bearing and the rest is carried away with the air exiting as side leakage (ref. 7). Therefore, considering its placement in an engine it is probable that the bearing and journal will be running hotter than the surrounding environment. Since the bearing's stiffness and damping properties 
define the rotordynamic stability of the system, accurate knowledge of the internal bearing temperatures for all operating conditions becomes an important piece of information when designing high speed rotating systems, such as gas turbine engines.

Investigating the temperature profile also provides an opportunity to ascertain the formation of thermal gradients, either axial or circumferential, in the bearing during operation. Unlike a rigid fluid film bearing, where the film thickness is generally constant across its axial width, the spatially variable stiffness of compliant foil bearings allows for varying air film thicknesses that depend upon the resulting hydrodynamic pressures. The differences in film thickness cause nonuniform viscous heating that create localized foil temperature variations. Due to thermal expansion these gradients can result in distortion of the design shape of the top foil, leading to disruption of the formation of an air film and possible bearing failure (ref. 8). This type of failure mechanism is believed by the authors to explain a number of sudden failures encountered in the lab while operating foil bearings under various ambient temperature, speed and load conditions. These failures have occurred at ambient temperatures ranging from 23 to $540{ }^{\circ} \mathrm{C}$ and can be classified from minor, where full recovery is achievable through reduction in speed or load, to catastrophic, where both the bearing and journal undergo severe structural damage. An example of one such failure was the subject of a Master's project by Dykas who performed an analytical investigation into a test that resulted in complete destruction of the bearing's support structure and the formation of a large (15-mm-diameter), dime-sized hole in the journal (ref. 9). In this case the bearing was operating in a $540{ }^{\circ} \mathrm{C}$ ambient environment, $60 \mathrm{krpm}$ and supporting a load that was only 16 percent of its calculated load capacity based on the rule-of-thumb (ROT) equation (ref. 10). Results from his numerical modeling of the bearing-journal system suggest that axial thermal gradients coupled with centrifugal growth of the journal played a major role in the cause of the catastrophic failure.

The purpose of the current paper is to obtain an understanding of the steady-state internal temperature profile developed in an operating foil air bearing. The parametric study was conducted on a Generation III single-bump foil bearing instrumented with nine, type K thermocouples placed in the highly loaded region. The thermocouples were located at the bearing's middle and edges in order to collect localized temperatures and also to monitor the formation of axial and circumferential thermal gradients. Temperature data was collected as a function of speed and load in a room temperature environment. It is expected that the data contained in this report will assist in identifying the need for cooling requirements and the validation of improved foil air bearing computer models.

\section{Experimental Apparatus/Procedure}

\section{Instrumented Foil Bearing and Test Journal}

Shown in figure 3 is a full body drawing of the Generation III foil bearing used in the tests along with the location of the installed thermocouples. Generation III is a term that defines the design complexity of the bearing's support structure and is further explained in more detail in reference 10 . The bearing was nominally $50 \mathrm{~mm}$ in diameter and $41 \mathrm{~mm}$ in length. Internal temperatures were measured by instrumenting the bearing with nine, type $\mathrm{K}$ thermocouples in $0.81 \mathrm{~mm}$ sheaths arranged as shown in the figure. At each location the thermocouple was tack welded directly onto the backside of an individual bump that was in contact with the top foil. A close-up view of the thermocouple location on the bump foil is presented in figure 4. Placing the thermocouples at this juncture allowed for a more accurate measurement of the foil temperature and is also a non-intrusive method to provide a reasonable estimate of the temperature in the adjacent air film. Since the maximum heating due to shearing of the gas film is expected to occur in the thinnest air film thermocouples $2,3,5,6,8$, and 9 were placed on the bumps situated closest to the edge of the top foil. Thermocouples 1,4 , and 7 were added in the center of the bearing to improve the sensitivity of detecting any axial thermal gradients. For reference purposes thermocouples 3, 6, 9 and 2, 5, 8 are at the front and rear of the bearing, respectively. 
The mating test journal was prepared by first plasma spraying PS304, a high temperature solid lubricant coating, onto the surface and then placing it into a $540{ }^{\circ} \mathrm{C}$ oven for $100 \mathrm{hr}$ (ref. 11). After the heat treatment process the journal was affixed to the test rig and ground with an in-place grinding system to a final diameter of approximately $50.8 \mathrm{~mm}$ in order to achieve the manufacturer's specified bearing preload. Using a computer program based on the two-plane influence coefficient method the rig was balanced up to $50 \mathrm{krpm}$.

\section{Test Apparatus/Procedure}

The high-speed rig used for performing the tests is shown in figure 5 and is described in greater detail in reference 5 . The rig consists of a drive shaft that is supported by two hybrid, ceramic ball bearings that are lubricated by oil and cooled by circulated chilled water. An air impulse turbine attached to the main shaft is capable of driving the journal to a maximum rotational speed of $70000 \mathrm{rpm}$. Radial loading of the bearing is accomplished via a vertical cable system with one end attached to the bearing in a stirrup configuration and the other to a pneumatic load cylinder mounted below the test rig. The rod extending from the bearing loader acts as a moment arm to relay the bearing torque to a load cell. A scatter shield was placed around the bearing to insure safe operation.

The PS304 coated journal in an as-ground condition will undergo break-in cycles during initial operation (ref. 12). In order to ensure this effect does not influence the data the bearing and journal were together subjected to approximately 1700 start-stop cycles at $540{ }^{\circ} \mathrm{C}$. The start-stop cycles act as a polishing wear mechanism between the asperities of the top foil and coating, resulting in a smooth, glossy surface on the PS304 coating and the development of a solid lubricant layer on the foil surface. After the break-in cycles the final coating surface roughness was approximately $0.2 \mu \mathrm{m}$.

Testing was done at room temperature to provide a known constant ambient environment and to ensure that the thermocouple readings were not influenced by any other heat source. The test procedure that was followed began by first operating the bearing at a constant speed while it supported a load of 8.9 $\mathrm{N}(2 \mathrm{lb})$ which is the weight of the bearing, bearing donut and loading cable. Once the thermocouple readings reached their steady-state value, a period typically lasting 15 minutes, the journal speed was increased by approximately $2 \mathrm{krpm}$ and an additional $35.6 \mathrm{~N}(8 \mathrm{lb})$ of load was applied to the bearing by the pneumatic loader and cable system. The load was held for 15 minutes to allow the thermocouple readings to stabilize. Then, the journal speed was again increased and an additional $44.5 \mathrm{~N}(10 \mathrm{lb})$ was applied. This process was continued in increments of $44.5 \mathrm{~N}$ until reaching the final load of $222 \mathrm{~N}(50 \mathrm{lb})$. Temperature measurements for all nine thermocouples were continually collected via a computer data acquisition program and stored in a spreadsheet file. Based on vibration limits of the test rig the tests were conducted at speeds from 20 to $50 \mathrm{krpm}$.

\section{Discussion of Results}

Before initiating the main research program, tests were conducted to evaluate the level of measurement uncertainty in the test method and its effect on the temperature output of the nine thermocouples. These preliminary tests consisted of collecting temperature data from five repeated tests on the same bearing, conducted over a five day period with the bearing operating at $20 \mathrm{krpm}$ and supporting a $222 \mathrm{~N}$ radial load. The results from these repeatability tests are graphically presented in figure 6. Each column represents one of the nine thermocouples and its height corresponds to the mean of the data. The accompanying error bars were determined from performing a t-test distribution analysis on the data that gives a 95 percent confidence interval for future test results (ref. 13). According to the statistical analysis the smallest data span from the mean was $\pm 3.5^{\circ} \mathrm{C}$ for thermocouple number 8 and the largest was $\pm 10^{\circ} \mathrm{C}$ for thermocouple number 1 . Therefore, as a conservative estimate, there is a 95 percent 
probability that the temperatures presented in this paper have measurement repeatability error no greater than $\pm 10{ }^{\circ} \mathrm{C}$.

Shown graphically in figure 7 are plots of real time temperature data for the nine thermocouples collected during a bearing test at $40 \mathrm{krpm}$ from start to finish and their behavior is representative of the output observed for the other test runs. The initial temperature rise was caused by both the bearing's preload and from supporting its own weight of $9 \mathrm{~N}$. Afterward, successive step changes in temperature signify a radial load increase applied to the bearing from the pneumatic loader and ending with the total supported load of $222 \mathrm{~N}$ (50 lbs). The step lengths confirm that each load condition was held for approximately 15 minutes to insure the temperatures had stabilized.

Test results encompassing the entire matrix of speed and load conditions are summarized in tables 1(a) to 1(d). The temperature and load data are in Centigrade and Newtons, respectively, with their conversions into English units provided in parentheses. According to the data there is a heat generation zone in the fluid film between thermocouple sets 1, 2, 3 and 4, 5, 6 followed by heat dissipation between thermocouple sets 4, 5, 6 and 7, 8, 9. At $20 \mathrm{krpm}$ the temperature distribution is fairly symmetric about the bearing's center but, as figure 8 shows, becomes more skewed toward the rear of the bearing at $50 \mathrm{krpm}$. The nonsymmetry at the higher speeds might be a result of bearing design or the differences in the front and rear heat conduction and convection rates becoming more pronounced due to the increased viscous heat generation and the orientation of the scatter shield. When the scatter shield is in place, the front of the bearing is open to the surrounding ambient environment whereas the rear is in an enclosed space.

The data indicate that, for a bearing operating at a constant speed, an increase in the radial load will cause the bearing's internal temperatures to rise. The same holds true if the situation is reversed and the load is held constant while the speed is raised. To illustrate this behavior, temperatures from thermocouples 1, 2, and 3 taken at $30 \mathrm{krpm}$ are graphed in figures 9 and 10 . Neither of these responses are unexpected since both actions have some effect on the velocity gradient in the fluid film and, hence, the magnitude of the viscous shear. It should be noted, however, that an equivalent comparison of bearing temperatures at two different speeds cannot be made at the same radial load since the load capacity of foil bearings is dependent upon the rotational speed of the journal. As journal speed increases so does the maximum load the bearing can sustain.

A more accurate comparison can be made by converting the applied load into a percentage of the bearing's maximum load capacity for that speed. Maximum load capacity can be estimated by using the empirical rule-of-thumb (ROT) equation proposed in reference 10 . Then, by dividing the applied load by the ROT calculated load capacity the percentage of maximum load capacity ( $\% \mathrm{LC})$ is realized. The ROT equation is written as

$$
\mathrm{LC}=\mathscr{D L D}{ }^{2} \Omega
$$

where

$\mathscr{D}$ is the load capacity coefficient, $\mathrm{N} /\left(\mathrm{mm}^{3} \cdot \mathrm{krpm}\right)$

LC is the maximum steady-state load that can be supported, $\mathrm{N}$

$\mathrm{L}$ is the bearing axial length, $\mathrm{mm}$

$\mathrm{D}$ is the shaft diameter, $\mathrm{mm}$

$\Omega$ is the shaft speed in thousand rpm (krpm)

For example, the geometric dimensions for the test bearing are $\mathrm{L}=40.6 \mathrm{~mm}, \mathrm{D}=50.8 \mathrm{~mm}$. Assuming $\mathscr{D}=2.2 \times 10^{-4}$ for a run-in bearing and journal and $\Omega=20 \mathrm{krpm}$, the maximum load, LC, is $456 \mathrm{~N}$. For the applied radial load of $178 \mathrm{~N}$, the $\% \mathrm{LC}=39$ percent. Using data from thermocouple number 1 as an example the temperature values are plotted for each speed in figure 11. According to this figure a bearing operating at 30 percent LC at $40 \mathrm{krpm}$ will be about twice as hot as a bearing operating at $20 \mathrm{krpm}$ under 
the same load condition. There also seems to be a trend with the effect of load being more pronounced in determining temperature as rotational speed is increased as evidenced by the greater sloping of the lines from 20 to $50 \mathrm{krpm}$.

The most intriguing results from the tests are with respect to the locations of the highest temperatures. For each speed and load condition the three highest temperatures occurred near the middle of the bearing at thermocouples 1,4 , and 7 with 4 being the hottest. Based on elementary fluid dynamics this would suggest that the minimum film thicknesses reside in the middle of the bearing. This assumption, however, contradicts analytical studies that predict the behavior of compliant foil bearings. In theory, the compliant support structure of foil bearings encourages the minimum air film thickness to be located at the edges of the top foil where the pressure is ambient, such as at thermocouples 5 or 6 . In the middle of the bearing, where the hydrodynamic pressure is the highest, a thicker fluid film develops because of greater foil deflections. Obviously, having the maximum temperatures occurring in the middle of the bearing instead of at the edges is a contradiction between the two principles and may indicate the presence of some other phenomena.

One plausible explanation for the unexpected temperature profile may be related to an incomplete exchange of air entering and exiting the bearing. During operation, the internal hydrodynamic pressure gradient is the mechanism responsible for regulating this continuous flow of air. However, it may be possible that, due to the bearing's axial length, the fluid's rotational inertia and a design feature incorporated into the bearing to minimize side leakage (ref. 10), the magnitude of the pressure gradient is insufficient to force all the air out of the bearing. Left in the middle of the bearing is a slug of fluid trapped in the circumferential flow. Salehi briefly suggested this possibility in reference 7 and there is further evidence to support this hypothesis from analytical results obtained from a newly developed fluid modeling code by Carpino that is based on his recent work (ref. 14). If this is the case, the confined fluid slug continues to heat from viscous shear until reaching an equilibrium condition from heat dissipation via conduction into the bearing, journal and the adjacent air that eventually exits the bearing as side leakage. The fact that thermocouples 8 and 9 are not hotter than the upstream thermocouples 5 and 6 may indicate that the hot side leakage air is exiting farther downstream past thermocouples 8 and 9 or it may provide evidence that a majority of the heat is dissipating via conduction into the bearing and journal.

With regards to thermal gradients, the temperature profile data indicate their existence in the bearing for all test conditions with the greatest magnitude always acting in the axial direction between the bearing's center and outer edges. Circumferential thermal gradients, on the other hand, were found to be negligible due to the small temperature differences produced in this direction. The largest axial thermal gradient consistently formed across the $14 \mathrm{~mm}$ distance between thermocouples 4 and 6 . A plot of this gradient as a function of speed and \%LC is presented in figure 12. A comparison of the individual curves shows that increasing the speed while retaining the same \%LC results in a more severe gradient. For example, at approximately $26 \% \mathrm{LC}$ the thermal gradient was $0.79{ }^{\circ} \mathrm{C} / \mathrm{mm}$ at $20 \mathrm{krpm}$ but rose to $1.46{ }^{\circ} \mathrm{C} / \mathrm{mm}$ at $30 \mathrm{krpm}, 2.32{ }^{\circ} \mathrm{C} / \mathrm{mm}$ at $40 \mathrm{krpm}$ and $3.78^{\circ} \mathrm{C} / \mathrm{mm}$ at $50 \mathrm{krpm}$. The slope of the curves also suggests that load becomes more influential on the resulting thermal gradient as the speed is increased. For example, at $40 \mathrm{krpm}$ and $6.5 \% \mathrm{LC}$, the gradient was $2.05{ }^{\circ} \mathrm{C} / \mathrm{mm}$ and only rose 19 percent to $2.44{ }^{\circ} \mathrm{C} / \mathrm{mm}$ at $33 \% \mathrm{LC}$. However, at $50 \mathrm{krpm}$, increasing the load from 5 to $26 \% \mathrm{LC}$ resulted in a 36 percent gradient increase from 2.8 to $3.8^{\circ} \mathrm{C} / \mathrm{mm}$.

The lack of bearing failure during the test program indicates that, up to the levels generated during testing, this type of bearing (bump foil) can tolerate the presence of thermal gradients in its support structure. However, the previously mentioned case study performed by Dykas proves that if the magnitudes of the gradients rise to dangerous levels they can cause catastrophic failure of both the bearing and shaft. This must be kept in mind when incorporating foil air bearings into a complex thermal system that has multiple heat sources, such as a gas turbine engine, as they could exacerbate the thermal gradients that are inherently produced in the bearing during operation. Therefore, it is highly recommended that foil air bearings be thoroughly tested under conditions that match the operating 
environment in which they'll be placed in order to evaluate the magnitude of the resulting thermal gradients and, if they are at dangerous levels, evaluate methods to control them.

\section{Concluding Remarks}

A series of tests were conducted at room temperature to determine the temperature distribution in a compliant, bump-type foil bearing under various speed and load conditions. The test results indicate that speed and load have an effect on heat generation with speed being the more influential parameter. The temperature distribution in the bearing was fairly symmetric but became a bit skewed toward one end of the bearing as the speed increased. This may have been a result of bearing design or differences in thermal dissipation rates due to one end of the bearing being exposed to ambient air and the other insulated by the test rig and scatter shield. The maximum temperatures in the bearing did not occur at the edge of the bearing where the minimum film thickness is theorized to be located but in the middle of the bearing where the air film is assumed to be thicker. It is postulated that a slug of air remains trapped in the circumferential flow in the bearing where it is continuously heated via viscous shear until reaching a thermal equilibrium condition. The tests also suggest that these bearings can sustain steady-state operation in the presence of thermal gradients, at least at the levels presented in this report.

It is expected that temperature data collected from these tests will provide information useful for the validation of future analytical modeling codes and help determine the need to employ any active cooling techniques.

\section{References}

1. Heshmat, H.: "Advancements in the Performance of Aerodynamic Foil Journal Bearings: High Speed and Load Capability," ASME Tribology Conference, Paper No. 93-Trib-32, 1993.

2. DellaCorte, C.: "The Evaluation of a Modified Chrome Oxide Based High Temperature Solid Lubricant Coating for Foil Gas Bearings," NASA/TM-1998-20860, 1998.

3. M.J. Valco and C. DellaCorte: "Oil-Free Turbomachinery Technology for Regional Jet, Rotorcraft and Supersonic Business Jet Propulsion Engines," Presented at the 16th International Symposium on Air Breathing Engines, Cleveland, OH, Aug. 31-Sept. 5, 2003

4. Harman, R.: “Gas Turbine Engineering,” $1^{\text {st }}$ Edition, John Wiley \& Sons, Inc., pp. 182-184, 1981.

5. DellaCorte, C.: "A New Foil Air Bearing Test Rig for Use to $700{ }^{\circ} \mathrm{C}$ and $70000 \mathrm{rpm}$," NASA TM-107405, 1997.

6. Howard, S.A., DellaCorte, C., Valco, M.J., Prahl, J.M., and Heshmat, H.: "Dynamic Stiffness and Damping Characteristics of a High Temperature Air Foil Journal Bearing." STLE Tribology Transactions, Vol. 44, No. 4, pp. 657-663, 2001.

7. Salehi, M., Swanson, E., and Heshmat, H.: "Thermal Features of Compliant Foil Bearings-Theory and Experiments,” ASME Journal of Tribology, Vol. 123, pp. 566-571, 2001.

8. Ruscitto, D., McCormick, J., and Gray, S.: "Hydrodynamic Air Lubricated Compliant Surface Bearing for an Automotive Gas Turbine Engine - I - Journal Bearing Performance," NASA CR-135368, April 1978. 
9. Dykas, B.: "Investigation of Thermal and Rotational Contributions to the Catastrophic Failure Mechanism of a Thin-Walled Journal Operating with Foil Air Bearings," Master's Thesis, Case Western Reserve University, May, 2003.

10. DellaCorte, C. and Valco, M.J.: "Load Capacity Estimation of Foil Air Journal Bearings for Oil-Free Turbomachinery Applications," STLE Tribology Transactions, Vol. 43, No. 4, pp. 795-801, 2000.

11. DellaCorte, C.: "The Effects of Substrate Material and Thermal Processing Atmosphere on the Strength of PS304: A High Temperature Solid Lubricant Coating," NASA/TM-2002-211483, September, 2002.

12. Radil, K., Howard, S., and Dykas, B.: "The Role of Radial Clearance on the Performance of Foil Air Bearings," STLE Tribology Transactions, Vol. 45, No. 4, pp. 485-490, 2002.

13. Figliola, R.S. and Beasley, D.E.: "Theory and Design for Mechanical Measurements," John Wiley \& Sons, Inc., pp. 117-119, 1991.

14. Carpino, M. and Talmage, G.: "A Fully Coupled Finite Element Formulation for Elastically Supported Foil Journal Bearings," STLE Tribology Transactions, Vol. 46, No. 4, pp.560-565, 2003.

TABLE 1.-TEMPERATURE RESULTS FOR THE NINE THERMOCOUPLES [Temperatures in Parentheses are in ${ }^{\circ} \mathrm{F}$.]

(a) $20 \mathrm{krpm}$

\begin{tabular}{|c|c|c|c|c|c|c|c|}
\hline & Initial & $\begin{array}{c}9 \mathrm{~N} \\
(2 \mathrm{lbs})\end{array}$ & $\begin{array}{c}44 \mathrm{~N} \\
(10 \mathrm{lbs})\end{array}$ & $\begin{array}{c}89 \mathrm{~N} \\
(20 \mathrm{lbs})\end{array}$ & $\begin{array}{c}133 \mathrm{~N} \\
(30 \mathrm{lbs})\end{array}$ & $\begin{array}{c}178 \mathrm{~N} \\
(40 \mathrm{lbs})\end{array}$ & $\begin{array}{c}222 \mathrm{~N} \\
(50 \mathrm{lbs})\end{array}$ \\
\hline $\mathrm{TC} \# 1$ & $20(68)$ & $67(152)$ & $69(156)$ & $74(165)$ & $81(177)$ & $86(186)$ & $90(194)$ \\
\hline $\mathrm{TC} \# 2$ & $21(69)$ & $62(144)$ & $65(149)$ & $70(158)$ & $76(168)$ & $81(177)$ & $85(185)$ \\
\hline $\mathrm{TC} \# 3$ & $19(67)$ & $59(139)$ & $61(142)$ & $66(151)$ & $72(161)$ & $77(170)$ & $80(176)$ \\
\hline $\mathrm{TC} \# 4$ & $21(70)$ & $74(166)$ & $77(170)$ & $82(180)$ & $90(194)$ & $96(204)$ & $101(213)$ \\
\hline $\mathrm{TC} \# 5$ & $21(70)$ & $64(147)$ & $67(152)$ & $71(160)$ & $77(170)$ & $82(180)$ & $86(187)$ \\
\hline TC \#6 & $20(68)$ & $64(147)$ & $66(151)$ & $71(159)$ & $77(171)$ & $82(180)$ & $86(186)$ \\
\hline TC \#7 & $19(67)$ & $70(158)$ & $72(162)$ & $78(173)$ & $86(187)$ & $92(197)$ & $97(206)$ \\
\hline TC \#8 & $19(67)$ & $62(143)$ & $65(149)$ & $69(157)$ & $76(168)$ & $81(177)$ & $84(184)$ \\
\hline TC \#9 & $18(66)$ & $58(137)$ & $61(142)$ & $65(149)$ & $72(161)$ & $77(170)$ & $81(178)$ \\
\hline
\end{tabular}


TABLE 1.-TEMPERATURE RESULTS FOR THE NINE THERMOCOUPLES (Continued) [Temperatures in Parentheses are in ${ }^{\circ} \mathrm{F}$.]

(b) $30 \mathrm{krpm}$

\begin{tabular}{|c|c|c|c|c|c|c|c|}
\hline & Initial & $\begin{array}{c}9 \mathrm{~N} \\
(2 \mathrm{lbs})\end{array}$ & $\begin{array}{c}44 \mathrm{~N} \\
(10 \mathrm{lbs})\end{array}$ & $\begin{array}{c}89 \mathrm{~N} \\
(20 \mathrm{lbs})\end{array}$ & $\begin{array}{c}133 \mathrm{~N} \\
(30 \mathrm{lbs})\end{array}$ & $\begin{array}{c}178 \mathrm{~N} \\
(40 \mathrm{lbs})\end{array}$ & $\begin{array}{c}222 \mathrm{~N} \\
(50 \mathrm{lbs})\end{array}$ \\
\hline TC \#1 & $20(68)$ & $90(194)$ & $92(198)$ & $98(208)$ & $104(219)$ & $110(230)$ & $117(243)$ \\
\hline TC \#2 & $21(70)$ & $84(184)$ & $88(191)$ & $94(201)$ & $100(212)$ & $106(222)$ & $112(234)$ \\
\hline TC \#3 & $19(67)$ & $77(170)$ & $79(174)$ & $83(182)$ & $89(192)$ & $94(201)$ & $100(212)$ \\
\hline TC \#4 & $21(70)$ & $102(216)$ & $106(222)$ & $112(234)$ & $119(247)$ & $126(259)$ & $134(274)$ \\
\hline TC \#5 & $21(70)$ & $86(187)$ & $90(194)$ & $96(204)$ & $102(215)$ & $108(226)$ & $113(236)$ \\
\hline TC \#6 & $20(68)$ & $83(182)$ & $87(188)$ & $92(197)$ & $98(208)$ & $103(217)$ & $109(229)$ \\
\hline TC \#7 & $19(67)$ & $94(202)$ & $98(209)$ & $105(221)$ & $112(233)$ & $119(246)$ & $127(261)$ \\
\hline TC \#8 & $19(67)$ & $83(182)$ & $88(190)$ & $93(200)$ & $99(211)$ & $106(222)$ & $112(233)$ \\
\hline TC \#9 & $18(66)$ & $76(168)$ & $79(174)$ & $84(183)$ & $89(193)$ & $96(204)$ & $102(215)$ \\
\hline
\end{tabular}

(c) $40 \mathrm{krpm}$

\begin{tabular}{|c|c|c|c|c|c|c|c|}
\hline & Initial & $\begin{array}{c}9 \mathrm{~N} \\
(2 \mathrm{lbs})\end{array}$ & $\begin{array}{c}44 \mathrm{~N} \\
(10 \mathrm{lbs})\end{array}$ & $\begin{array}{c}89 \mathrm{~N} \\
(20 \mathrm{lbs})\end{array}$ & $\begin{array}{c}133 \mathrm{~N} \\
(30 \mathrm{lbs})\end{array}$ & $\begin{array}{c}178 \mathrm{~N} \\
(40 \mathrm{lbs})\end{array}$ & $\begin{array}{c}222 \mathrm{~N} \\
(50 \mathrm{lbs})\end{array}$ \\
\hline TC \#1 & $20(68)$ & $118(244)$ & $116(240)$ & $121(249)$ & $128(262)$ & $137(278)$ & $152(296)$ \\
\hline TC \#2 & $21(70)$ & $112(233)$ & $113(235)$ & $118(244)$ & $124(255)$ & $133(271)$ & $148(289)$ \\
\hline TC \#3 & $19(67)$ & $97(207)$ & $97(206)$ & $101(213)$ & $107(224)$ & $114(237)$ & $127(252)$ \\
\hline TC \#4 & $21(70)$ & $137(278)$ & $136(276)$ & $141(286)$ & $149(301)$ & $160(320)$ & $176(339)$ \\
\hline TC \#5 & $21(70)$ & $114(237)$ & $114(238)$ & $119(247)$ & $126(259)$ & $134(273)$ & $149(291)$ \\
\hline TC \#6 & $20(68)$ & $108(227)$ & $107(225)$ & $111(232)$ & $118(245)$ & $127(260)$ & $141(276)$ \\
\hline TC \#7 & $19(67)$ & $126(259)$ & $125(257)$ & $131(268)$ & $139(283)$ & $150(302)$ & $167(323)$ \\
\hline TC \#8 & $19(67)$ & $112(233)$ & $112(234)$ & $117(243)$ & $124(255)$ & $133(271)$ & $148(289)$ \\
\hline TC \#9 & $18(66)$ & $97(207)$ & $97(207)$ & $102(216)$ & $109(229)$ & $117(242)$ & $131(259)$ \\
\hline
\end{tabular}

(d) $50 \mathrm{krpm}$

\begin{tabular}{|c|c|c|c|c|c|c|c|}
\hline & Initial & $\begin{array}{c}9 \mathrm{~N} \\
(2 \mathrm{lbs})\end{array}$ & $\begin{array}{c}44 \mathrm{~N} \\
(10 \mathrm{lbs})\end{array}$ & $\begin{array}{c}89 \mathrm{~N} \\
(20 \mathrm{lbs})\end{array}$ & $\begin{array}{c}133 \mathrm{~N} \\
(30 \mathrm{lbs})\end{array}$ & $\begin{array}{c}178 \mathrm{~N} \\
(40 \mathrm{lbs})\end{array}$ & $\begin{array}{c}222 \mathrm{~N} \\
(50 \mathrm{lbs})\end{array}$ \\
\hline TC \#1 & $20(68)$ & $147(296)$ & $144(291)$ & $152(305)$ & $162(323)$ & $172(342)$ & $183(361)$ \\
\hline TC \#2 & $21(70)$ & $146(295)$ & $146(295)$ & $156(312)$ & $166(330)$ & $176(349)$ & $188(371)$ \\
\hline TC \#3 & $19(67)$ & $119(246)$ & $117(243)$ & $124(255)$ & $132(269)$ & $141(286)$ & $151(304)$ \\
\hline TC \#4 & $21(70)$ & $168(335)$ & $168(335)$ & $181(357)$ & $193(379)$ & $205(401)$ & $217(423)$ \\
\hline TC \#5 & $21(70)$ & $146(295)$ & $146(294)$ & $154(309)$ & $162(324)$ & $172(342)$ & $183(361)$ \\
\hline TC \#6 & $20(68)$ & $131(267)$ & $128(263)$ & $136(277)$ & $143(290)$ & $154(309)$ & $163(326)$ \\
\hline TC \#7 & $19(67)$ & $157(315)$ & $156(313)$ & $166(331)$ & $177(351)$ & $190(374)$ & $202(395)$ \\
\hline TC \#8 & $19(67)$ & $144(291)$ & $142(288)$ & $151(304)$ & $160(320)$ & $171(339)$ & $181(358)$ \\
\hline TC \#9 & $18(66)$ & $119(246)$ & $118(245)$ & $126(259)$ & $134(274)$ & $144(291)$ & $154(309)$ \\
\hline
\end{tabular}




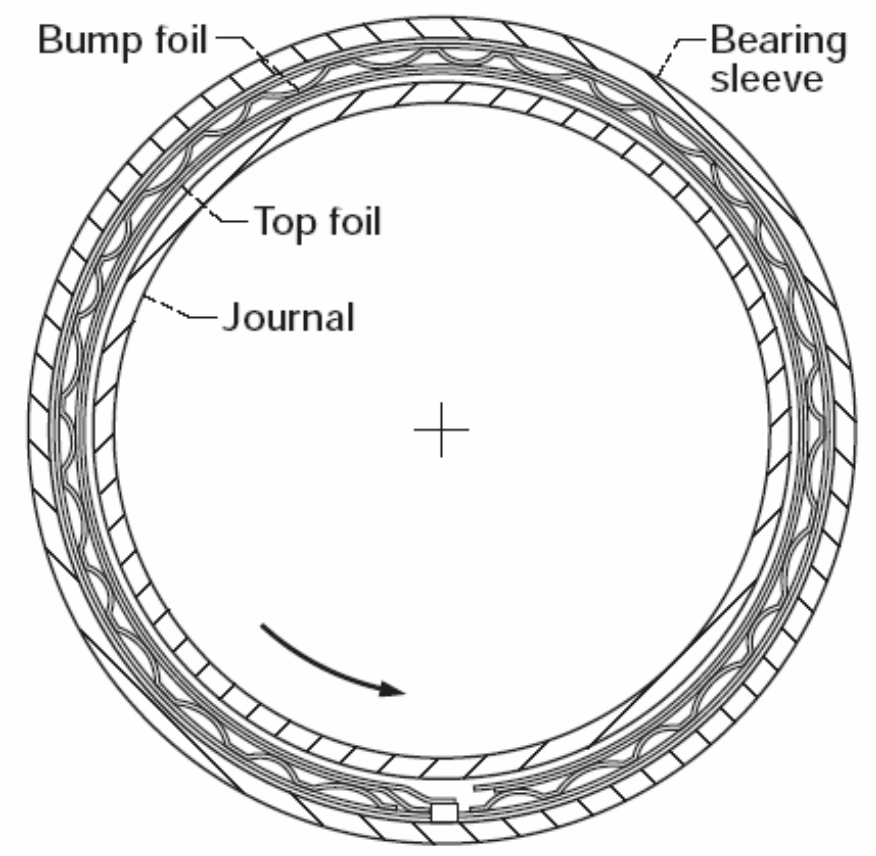

Figure 1. Cross-section of a Generation III foil air bearing.

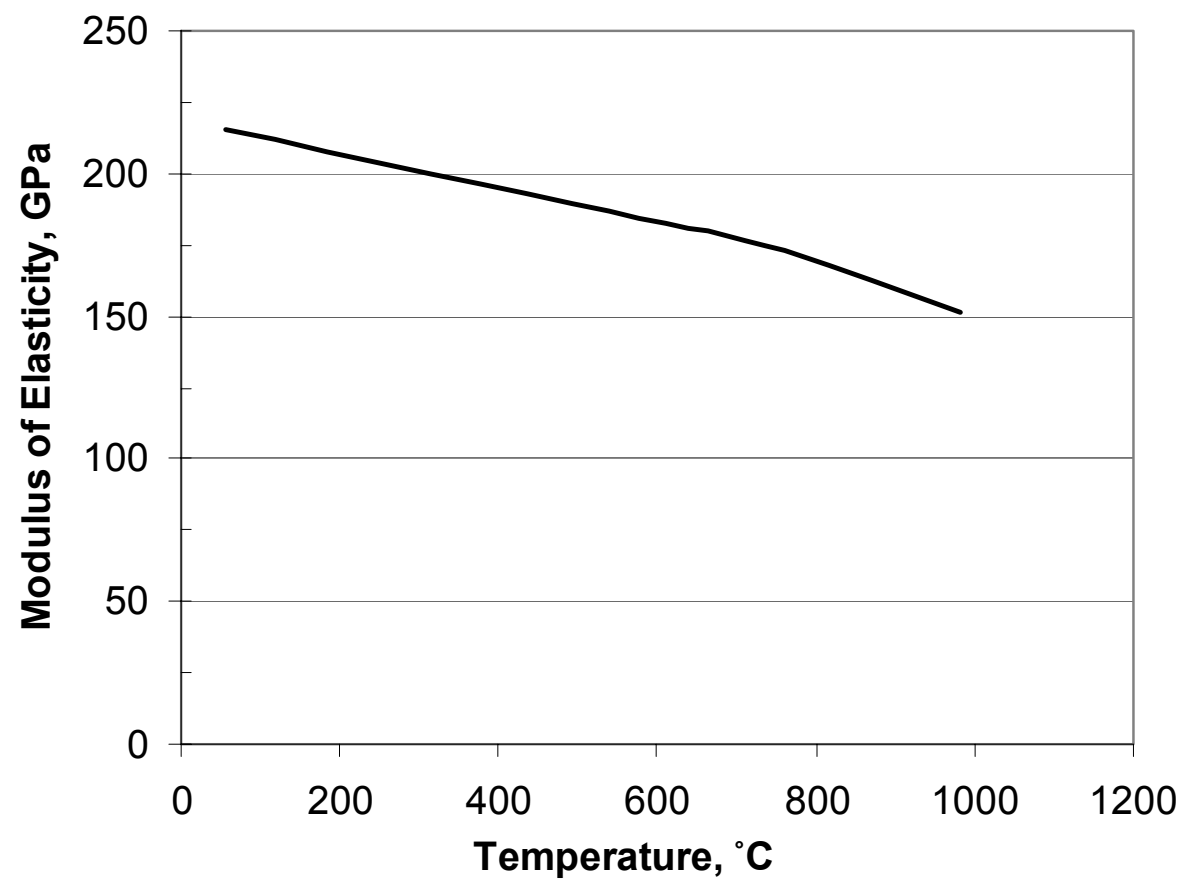

Figure 2. Modulus of elasticity as a function of temperature for the nickel based superalloy. 


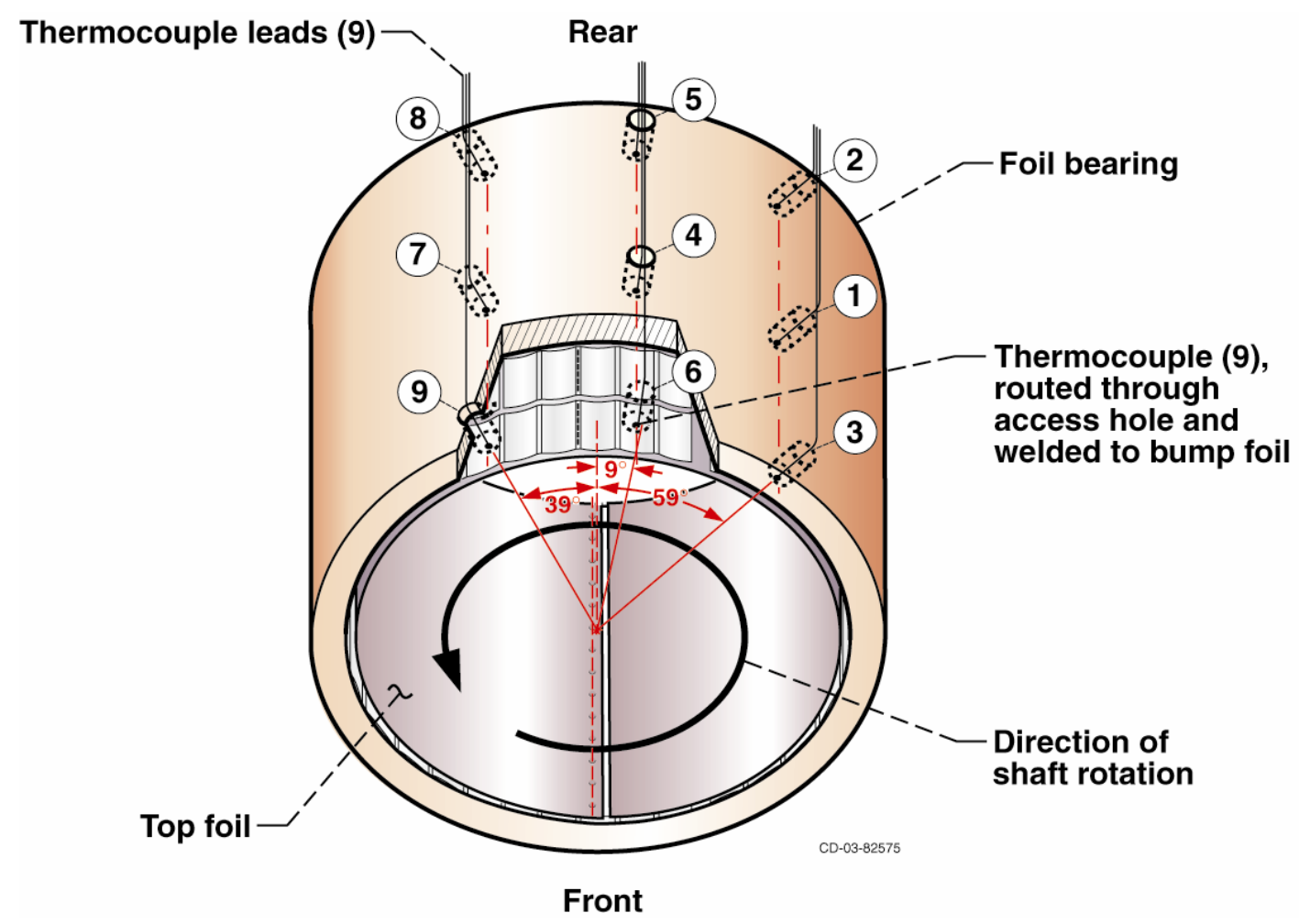

Figure 3. Schematic of the foil bearing showing journal rotational direction and locations of the nine thermocouples

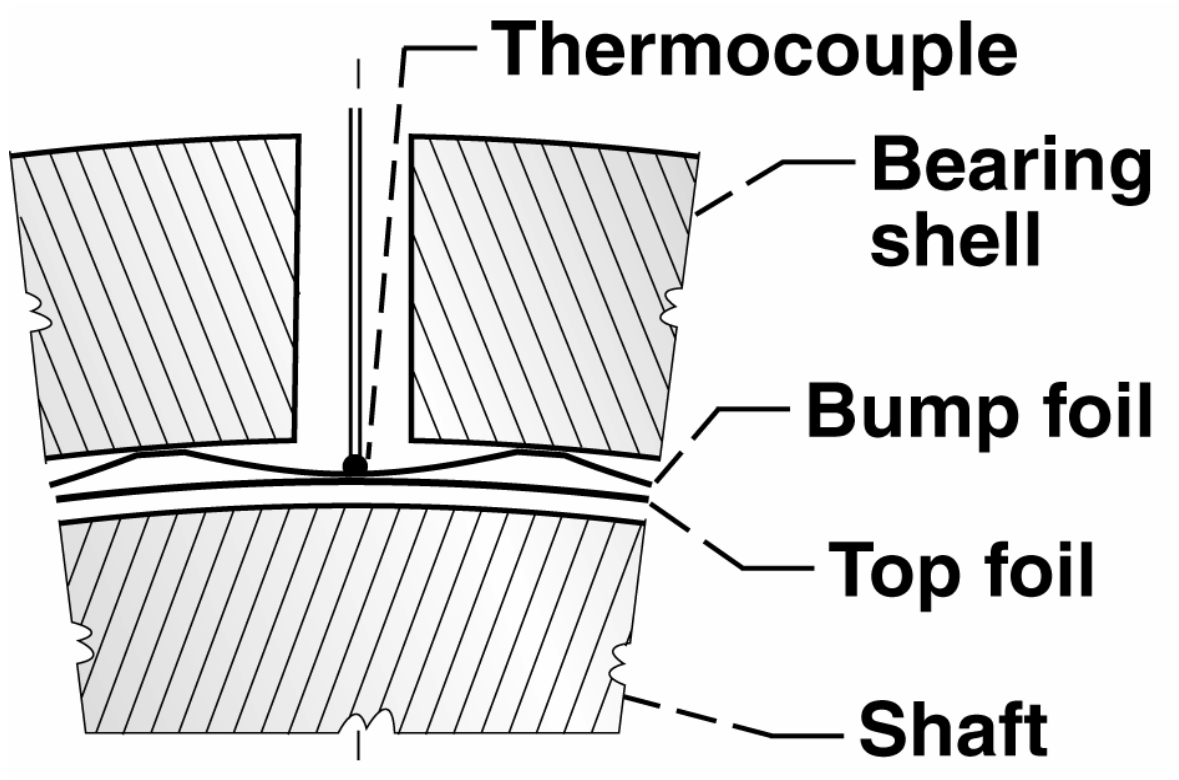

Figure 4. Close-up view of a thermocouple at the bump foil-top foil junction. 


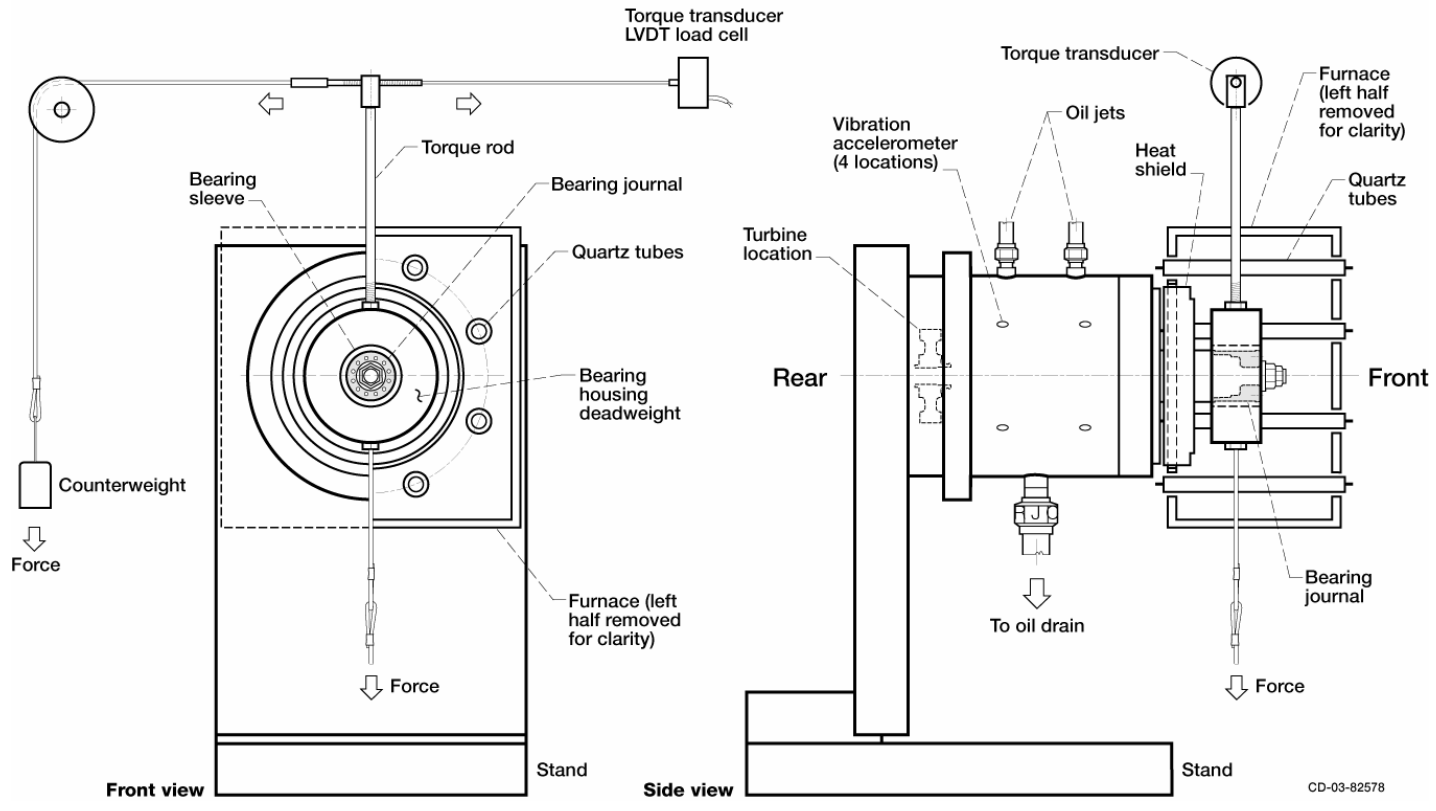

Figure 5. Schematic of the high-speed test rig and cable system for radial loading and torque measurement.

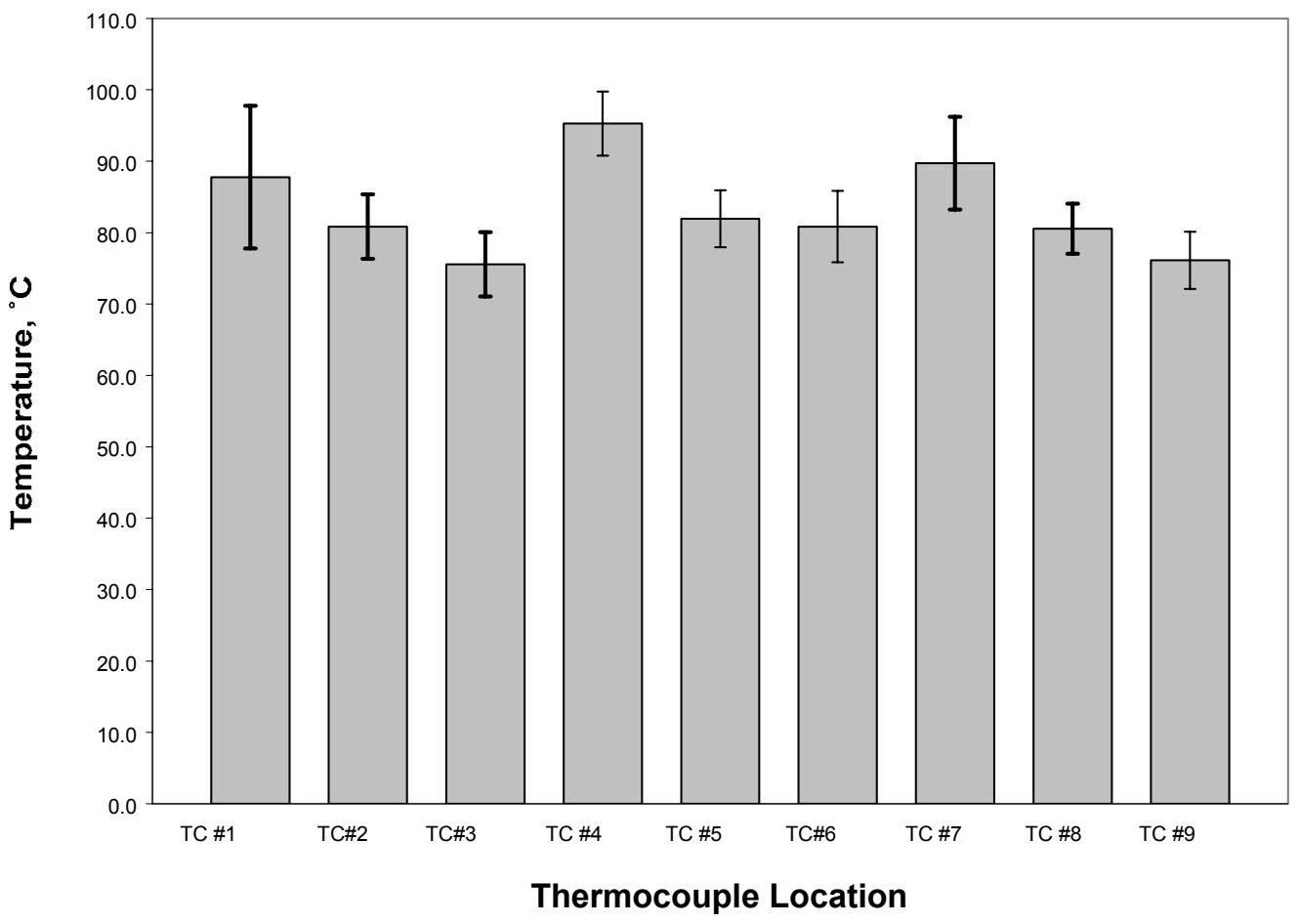

Figure 6. Repeatability test data taken with the bearing operating at $20 \mathrm{krpm}$ and supporting 222 N. Error bars represent a 95 percent confidence interval. 


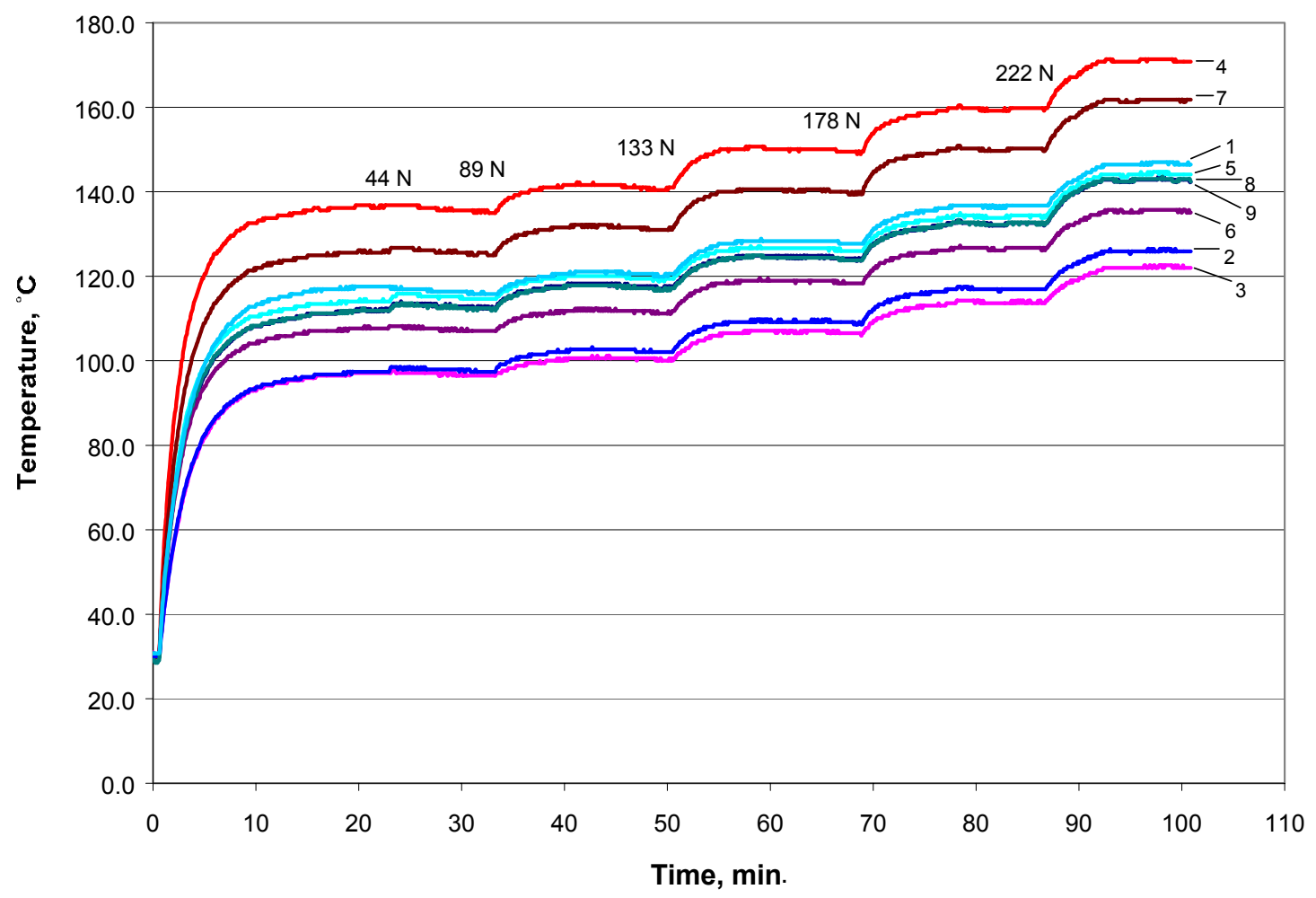

Figure 7. Temperature versus time curves at $40 \mathrm{krpm}$ with loads ranging from 9 to $222 \mathrm{~N}$. Numbers correspond to thermocouple locations in figure 3.

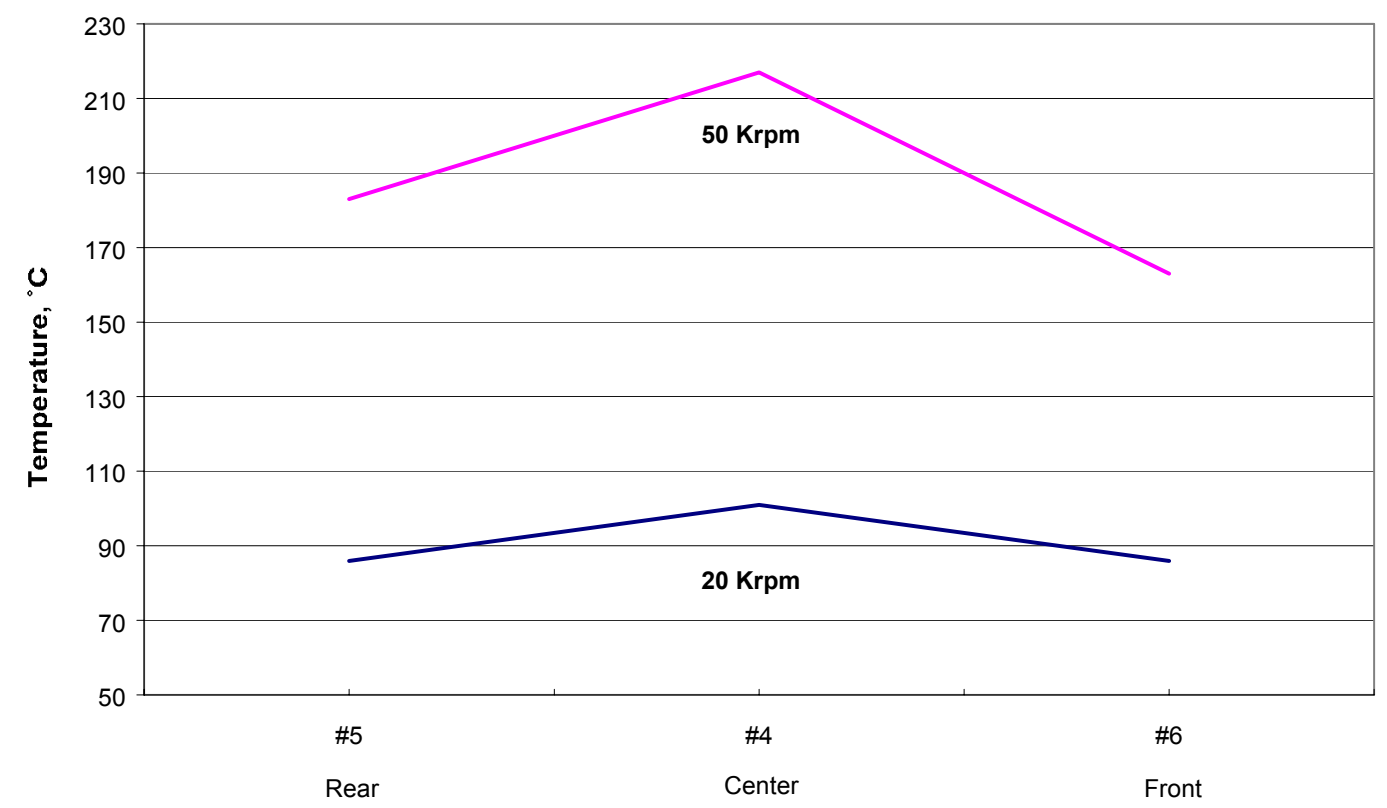

Thermocouple Location

Figure 8. Axial temperature distribution at $20 \mathrm{krpm}$ and $50 \mathrm{krpm}$. Load is $222 \mathrm{~N}$. 


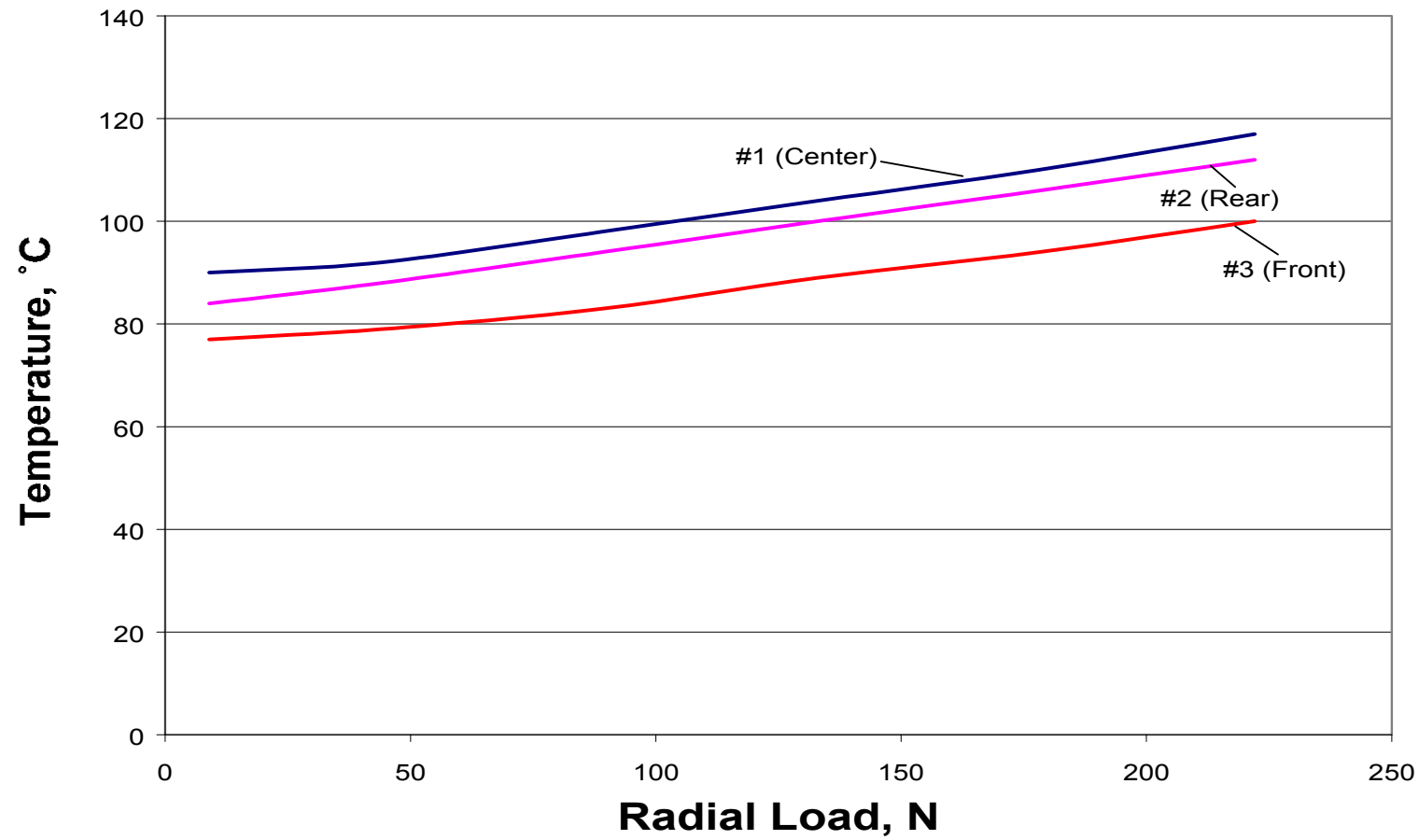

Figure 9. Bearing temperature response to an increase in the radial load. Bearing operating at $30 \mathrm{krpm}$.

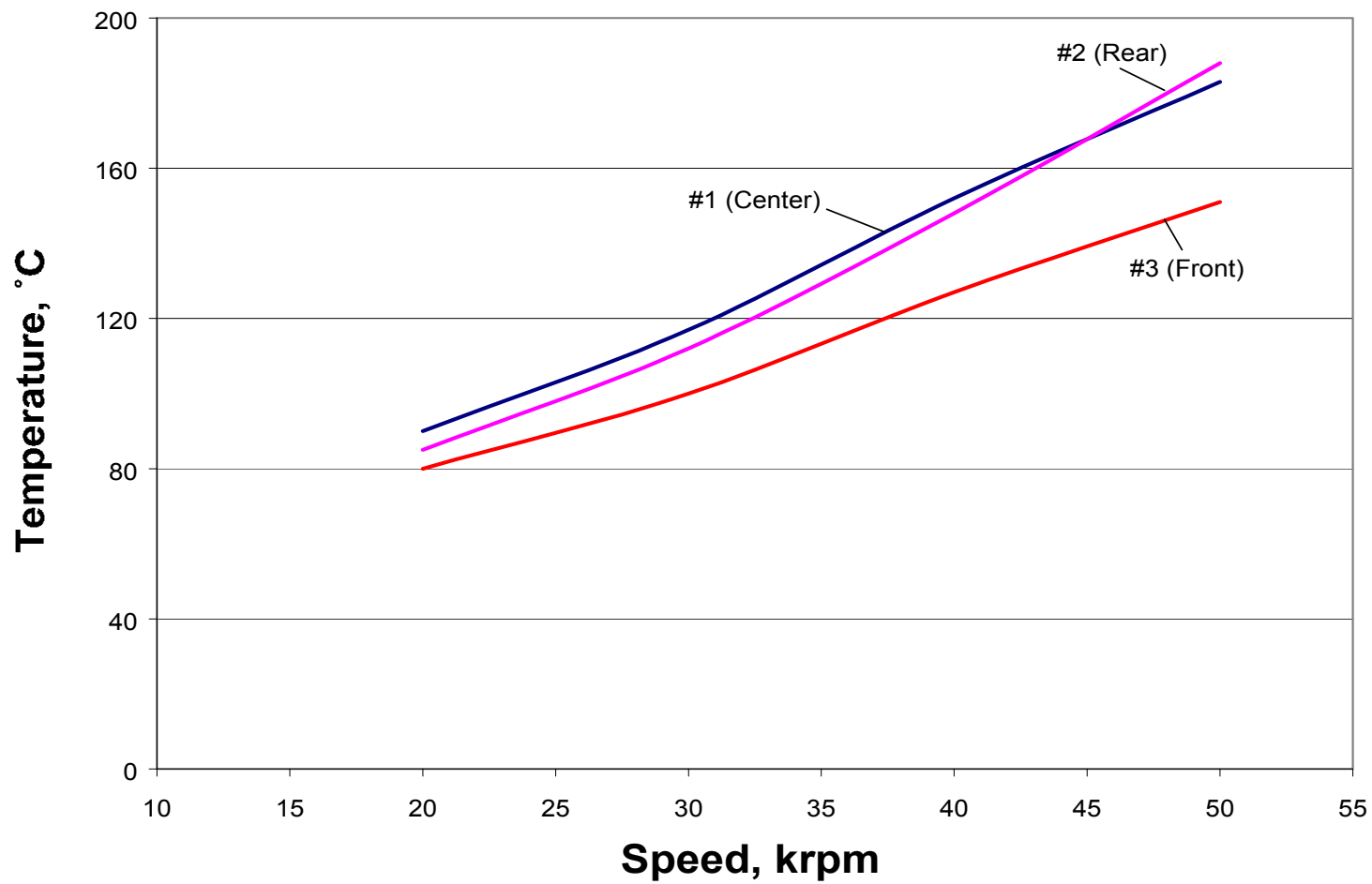

Figure 10. Bearing temperature response to an increase in journal speed. Load is $222 \mathrm{~N}$. 


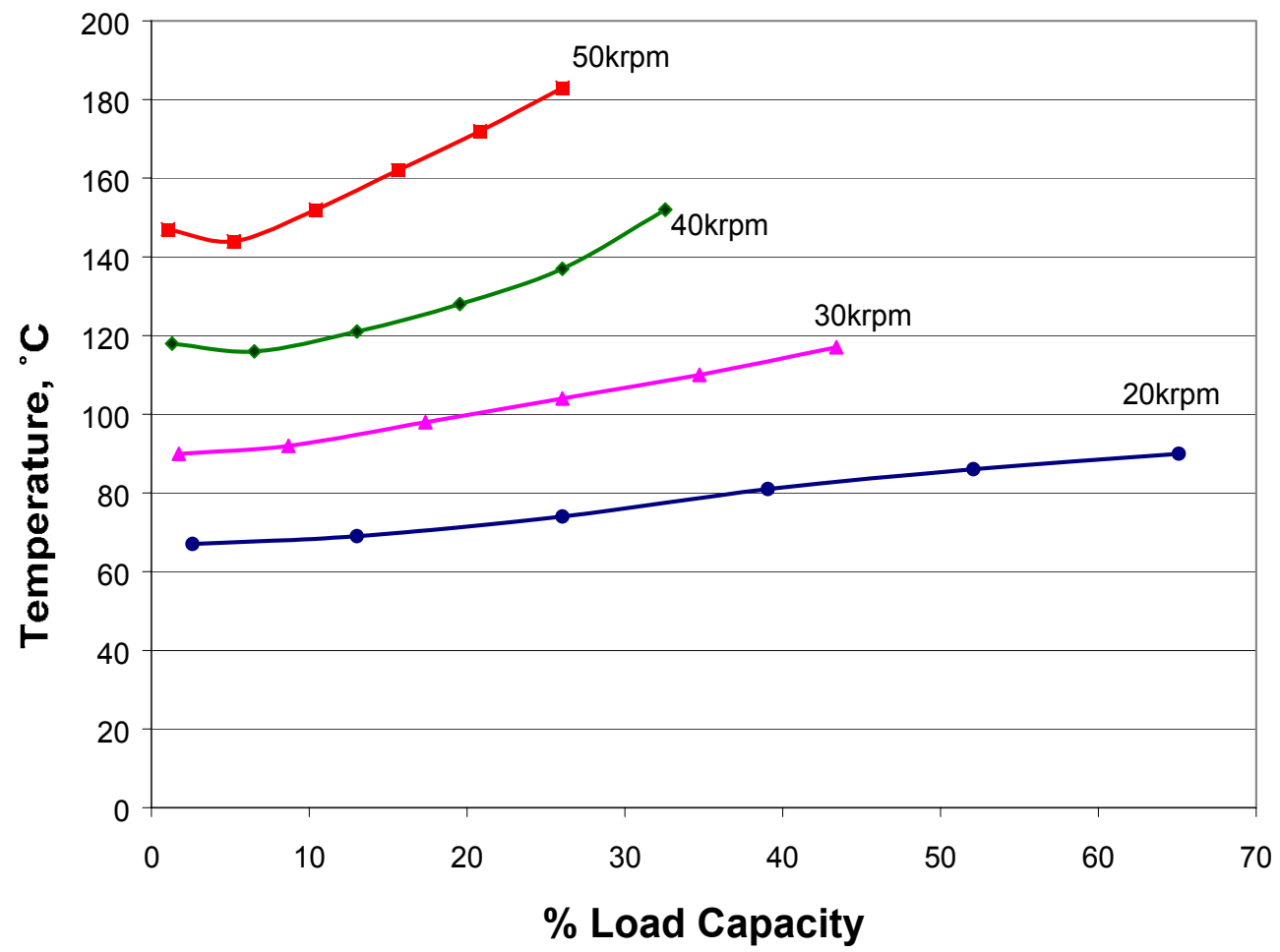

Figure 11. Temperature of thermocouple number 1 as a function of speed and load.

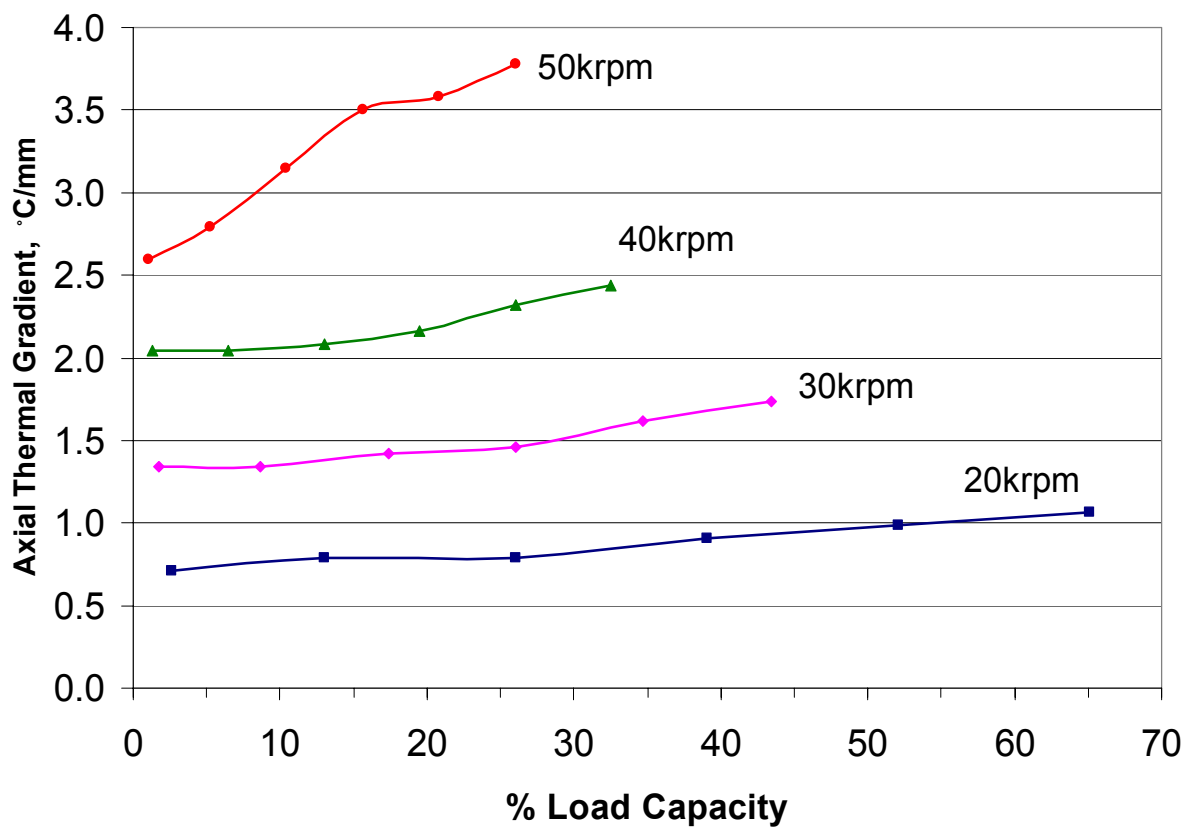

Figure 12. Axial thermal gradient between thermocouples number 4 and number 6 as a function of speed and load. 
Public reporting burden for this collection of information is estimated to average 1 hour per response, including the time for reviewing instructions, searching existing data sources, gathering and maintaining the data needed, and completing and reviewing the collection of information. Send comments regarding this burden estimate or any other aspect of this collection of information, including suggestions for reducing this burden, to Washington Headquarters Services, Directorate for Information Operations and Reports, 1215 Jefferson Davis Highway, Suite 1204, Arlington, VA 22202-4302, and to the Office of Management and Budget, Paperwork Reduction Project (0704-0188), Washington, DC 20503.

\begin{tabular}{|l|l|r|}
\hline 1. AGENCY USE ONLY (Leave blank) & $\begin{array}{c}\text { 2. REPORT DATE } \\
\text { May } 2004\end{array}$ & $\begin{array}{r}\text { 3. REPORT TYPE AND DATES COVERED } \\
\text { Technical Memoran }\end{array}$
\end{tabular}

\section{TITLE AND SUBTITLE}

An Experimental Investigation Into the Temperature Profile

of a Compliant Foil Air Bearing

6. AUTHOR(S)

Kevin Radil and Michelle Zeszotek

5. FUNDING NUMBERS

WBS-22-714-09-17

1L162211A47A

7. PERFORMING ORGANIZATION NAME(S) AND ADDRESS(ES)

8. PERFORMING ORGANIZATION

REPORT NUMBER

National Aeronautics and Space Administration

John H. Glenn Research Center at Lewis Field

Cleveland, Ohio 44135-3191

E-14575

\section{SPONSORING/MONITORING AGENCY NAME(S) AND ADDRESS(ES)}

National Aeronautics and Space Administration

Washington, DC 20546-0001

and

U.S. Army Research Laboratory

Adelphi, Maryland 20783-1145
10. SPONSORING/MONITORING AGENCY REPORT NUMBER

NASA TM-2004-213100

ARL-TR-3200

\section{SUPPLEMENTARY NOTES}

Prepared for the 2004 Annual Meeting and Exhibition sponsored by the Society of Tribologists and Lubrication Engineers, Toronto, Canada, May 17-20, 2004. Kevin Radil, U.S. Army Research Laboratory, NASA Glenn Research Center; and Michelle Zeszotek, Purdue University, Main Campus, West Lafayette, Indiana 47907. Responsible person, Kevin Radil, organization code 0300, 216-433-5047.

12a. DISTRIBUTION/AVAILABILITY STATEMENT 12b. DISTRIBUTION CODE

Unclassified - Unlimited

Subject Category: 07

Distribution: Nonstandard

Available electronically at http://gltrs.grc.nasa.gov

This publication is available from the NASA Center for AeroSpace Information, 301-621-0390.

\section{ABSTRACT (Maximum 200 words)}

A series of tests was performed to determine the internal temperature profile in a compliant bump-type foil journal air bearing operating at room temperature under various speeds and load conditions. The temperature profile was collected by instrumenting a foil bearing with nine, type $\mathrm{K}$ thermocouples arranged in the center and along the bearing's edges in order to measure local temperatures and estimate thermal gradients in the axial and circumferential directions. To facilitate the measurement of maximum temperatures from viscous shearing in the air film, the thermocouples were tack welded to the backside of the bumps that were in direct contact with the top foil. The mating journal was coated with a high temperature solid lubricant that, together with the bearing, underwent high temperature start-stop cycles to produce a smooth, steady-state run-in surface. Tests were conducted at speeds from 20 to $50 \mathrm{krpm}$ and loads ranging from 9 to $222 \mathrm{~N}$. The results indicate that, over the conditions tested, both journal rotational speed and radial load are responsible for heat generation with speed playing a more significant role in the magnitude of the temperatures. The temperature distribution was nearly symmetric about the bearing center at 20 and $30 \mathrm{krpm}$ but became slightly skewed toward one side at 40 and $50 \mathrm{krpm}$. Surprisingly, the maximum temperatures did not occur at the bearing edge where the minimum film thickness is expected but rather in the middle of the bearing where analytical investigations have predicted the air film to be much thicker. Thermal gradients were common during testing and were strongest in the axial direction from the middle of the bearing to its edges, reaching $3.78{ }^{\circ} \mathrm{C} / \mathrm{mm}$. The temperature profile indicated the circumferential thermal gradients were negligible.

14. SUBJECT TERMS

Foil air bearings; Gas bearings; Turbomachinery 15. NUMBER OF PAGES 21

\begin{tabular}{|c|c|c|}
\hline $\begin{array}{c}\text { 17. SECURITY CLASSIFICATION } \\
\text { OF REPORT } \\
\text { Unclassified }\end{array}$ & $\begin{array}{c}\text { 18. SECURITY CLASSIFICATION } \\
\text { OF THIS PAGE } \\
\text { Unclassified }\end{array}$ & $\begin{array}{c}\text { 19. SECURITY CLASSIFICATION } \\
\text { OF ABSTRACT } \\
\text { Unclassified }\end{array}$ \\
\hline
\end{tabular}



